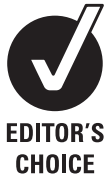

National Centre for Epidemiology and Population Health, Australian National University, Canberra, Australia

\section{Correspondence to}

Colin D Butler, Associate Professor, National Centre for Epidemiology and Population Health, Building 62, Australian National University, Canberra 0200, Australia;

colin.butler@anu.edu.au

Received 14 May 2009

Accepted 12 December 2009

\title{
Primary, secondary and tertiary effects of eco-climatic change: the medical response
}

\author{
Colin D Butler, David Harley
}

ABSTRACT

Climatic and ecological change threaten human health globally. Manifestations include lost species, vanishing glaciers and more frequent heavy rain. In the second half of this century, accelerating sea level rise is likely to cause crop loss, and population dislocation. These problems may be magnified by dysfunctional human responses, including conflict. The population health consequences of these events can be classified as primary, secondary and tertiary. Primary signs include the acute and chronic stress of heat waves, and trauma from increased bush fires and flooding. Secondary signs are indirect, such as an altered distribution of arthropod vectors, intermediate hosts and pathogens that will produce changes in the epidemiology of many infectious diseases. More severe future health consequences of climate change are classified here as tertiary effects. If moderate or severe climate change scenarios prove accurate then these manifestations will occur over large areas, and could include famine, war and significant population displacement. Such effects would threaten governance and health. The health professions must respond to these challenges, especially the task of recognising and seeking to minimise tertiary health consequences. The gap between what we know and what we need to know concerning these issues can be narrowed by a new field of medical practice. The framework for this emerging discipline includes climate change, ecology and global health. Combined, these dimensions may be called ecomedicine. Actions to reduce individual emissions, to promote active transport (with its 'co-benefit' of preventing chronic disease), and involvement in group action to protect the environment and to prevent war, informed by understanding of the health of individual patients and populations, will be central to the practice of ecomedicine.

\section{INTRODUCTION}

Fears of global apocalypse, especially large-scale nuclear war, have formed a psychological backdrop for many people since the dropping of the first atomic bomb in the second world war. However, until the onset of the current global financial crisis, the future for high income populations has seemed bright. This optimism is challenged by many scientists, $^{1-4}$ and doubts about the future affect many young people. ${ }^{5}$

Prominent as a cause for these doubts are climate change and the ecological crisis. The evidence for the latter includes the loss of species and impoverishment of ecosystems. Some obviously affect human health, such as the collapse of fish stocks. But there are many more subtle interactions, both causal and consequential, between climate and ecosystem change. ${ }^{1}$ Over the last 40 years ${ }^{6}$ climate change has slowly moved to centre stage, now reaching the US administration. The health consequences are also increasingly recognised. For example, in 2008 Margaret Chan, the World Health Organization's Director General, described climate change as one of 'three global crises looming on the horizon'.

Doctors have long played important roles in the pursuit of social justice, human rights, environmental protection and peace. ${ }^{8-10}$ Despite such involvement, going beyond individual patient care, the issues of climate change and global ecology may seem peripheral to the average medical graduate. The focus of ecomedicine $e^{11-13}$ may appear as arcane as microscope gazing once seemed. ${ }^{14}$ Theories of miasma were replaced by germ theory after the insights of Pasteur, Koch and others. Now all doctors have an understanding of microbiology and see this as central to human health. The study of microbes also played a vital role in the development of antibiotics. ${ }^{15}$ Indeed the discoverer of arguably the world's first antibiotic, René Dubos, finished his health career as one of the founding figures of this new discipline of ecomedicine. His co-authored book Only One Earth, was commissioned for what could be called the first 'Earth Summit', held in Stockholm in $1972 .^{11}$

The objectives of this paper are to bring these issues to the attention of all medical schools, and to encourage the development of this new discipline. Climate and ecological change are integral to human health. All doctors should be familiar with its basic elements, and some trainees should study the issue in depth. We also categorise the population health consequences of climatic and ecological change as primary, secondary and tertiary. We give examples of each, and stress that the most adverse and large scale health consequences will be these tertiary events, if unchecked human driven climate change continues. The emerging discipline of ecomedicine has a vital role in minimising and perhaps even avoiding these tertiary health events.

\section{ECOMEDICINE}

In recent years the term 'global health' has largely displaced Third World health and tropical medicine to describe and encompass the challenge of bringing health to all. ${ }^{16} 17$ A minority view holds that global health refers to 'transnational impacts of globalisation upon health determinants and health problems, beyond the control of individual nations. ${ }^{18}$ We sympathise with this view because it implicitly recognises that global health applies to the world's population, rather than only people 
in low income countries. The challenges we face will affect us all.

We propose the term ecomedicine to encompass the appropriate medical response to climatic and ecological changes. This system includes a biosphere (the thin crust of interacting life, atmosphere and land surface ${ }^{19}$ on our habitable planet) influenced by human action, leading to the current phase in earth's development being called the Anthropocene, ${ }^{420}$ a term coined to recognise the influence of human actions on the biosphere, sufficient in magnitude to move earth beyond the Holocene (a term for the interglacial era which began approximately 10000 years ago).

Every doctor understands the absolute necessity for humans to breathe, drink, eat and emit waste. We also know, though rarely contemplate, how substrates of atmosphere, food, water and waste co-exist and endlessly recycle in our environment and within the bodies of ourselves and our patients. Despoliation of local environments has been part of the human experience for millennia, ${ }^{21}$ but it is still difficult for most people to fully appreciate the degree to which the integrity of our environment is now disrupted on a global scale. It is best documented by human induced alteration of great elementary cycles, especially nitrogen, carbon and phosphorus. ${ }^{4} 22$ Manufactured contaminants can be detected in virtually all species everywhere, including remote poles and mountains. ${ }^{23} 24$

Paracelsus (and before him the Romans) recognised the dose makes the poison. ${ }^{25} \mathrm{~A}$ patient or population can be contaminated or infected by a low dosage and still function tolerably well. Our earth still functions. But beyond a critical threshold of exposure, dysfunction may become more apparent.

\section{ECOLOGY, CLIMATE AND HEALTH: MULTI-LEVEL EFFECTS}

Links between global ecology and human health were not reported until the 1960s. ${ }^{11}$ Although the possibility that humans could modify the global climate was raised in the 19th century, ${ }^{26}$ concerns about climate change and health are even more recent than are those for ecology and health. From a handful of papers in the late 1980s, ${ }^{6}{ }^{27}$ the literature on this issue has now become very extensive.

Our simple classification of health effects from climatic and ecological change is intended as a guide. We classify the effects as primary, secondary and tertiary. ${ }^{28}$ Primary effects arise from the direct impact of the physical system upon human health. Harm to humans is usually rapid and obvious, such as from heatwaves, forest fires, floods and storms, all of which are predicted to increase due to climate change. ${ }^{29}$ Climate change is likely to lead to reduced deaths from cold temperatures, especially in winter. ${ }^{30-32}$ Population displacement due to extreme eco-climatic events like Hurricane Katrina can also be conceptualised as a primary effect, influenced both by a very severe storm and the loss of wetlands, which removed a protective ecological buffer. ${ }^{33} 34$

\section{SECONDARY EFFECTS: INFECTIOUS DISEASES, ATOPY AND RESPIRATORY EFFECTS}

Secondary effects from eco-climatic change arise due to alterations in the ecology of vectors, parasites and host animals. Changes in the growth of allergens such as moulds can also be considered to fall into this category, ${ }^{35}{ }^{36}$ as do interactions between heatwaves and air pollutants. ${ }^{37}{ }^{38} \mathrm{Harm}$ to health is less rapid and obvious than for primary effects and is often causally contested, especially for infectious diseases. ${ }^{39-44}$ Many infectious diseases involve an interaction between humans, animal hosts, vectors and the infectious organism; thus, they may be sensitive to climatic conditions, especially temperature and rainfall. For instance, rainfall influences the reproduction and population of kangaroos, an animal host for Ross River virus, an Australian arbovirus transmitted by mosquitoes. ${ }^{45} 46$ Oncomelania hupensis, a snail host for Schistosoma japonicum in China, is also sensitive to temperature; a rise in temperature is likely to alter and expand the snail's distribution. ${ }^{47}$ An outbreak of the Hantavirus Puumula in Sweden in 2007 is believed to be related to reduced snow cover. It is postulated that this led infected voles to seek cover in barns, consequently increasing contact with humans, who inhaled virus from infected rodent excreta. $^{48}$

The dynamics of transmission cycles of vector borne diseases is temperature sensitive. For both malaria and arboviruses, warmer temperatures may shorten the extrinsic incubation period within the vector, while temperature, rainfall and humidity modify the abundance and longevity of the mosquito vectors and alter the behaviour of human and animal hosts. The extent to which climate change has already altered the epidemiology of malaria is particularly contested. ${ }^{41} 444950$ The epidemiology of malaria and its attribution to climate is complicated by drug resistance, poverty, land use changes and imperfect climatic and disease data. While it is true that these factors play an important role, it is almost certain that the importance of climate change will grow over time. For example an altitudinal increase in malaria transmission is expected in Africa along with prolongation of the transmission season..$^{50}$ The range of transmission of dengue fever epidemics is expanding; however, similar to malaria, there is debate concerning the extent to which this can be attributed to climate change. ${ }^{51}{ }^{52}$ Droughts may also facilitate mosquito breeding and human disease, including dengue fever, by necessitating increased domestic water storage.

The distribution of tick transmitted diseases, including Lyme disease and tick borne encephalitis, may have been altered by temperature and ecological changes. ${ }^{49}$ Climate change could also alter the severity and distribution of infectious diseases, such as HIV/AIDS and tuberculosis, especially via undernutrition, increased poverty, and more crowding.

\section{TERTIARY EFFECTS}

Tertiary effects operate at the intersection of climate, politics, and ecology, both human and non-human. The term 'tipping elements in the earth's climate system ${ }^{53}$ capture some of this dimension, as does the term 'great acceleration' with regard to our current position in the Anthropocene. ${ }^{4}$ However, neither idea fully articulates the consequences to global human public health from amplifying feedback between human action and growing environmental scarcity. ${ }^{28}$

For example, the conflict in Darfur, which to date has killed many more people than the European heat wave of 2003, is rarely seen as a result of adverse ecological and climate change ${ }^{54} 55$ Some object to such attribution because they consider it an example of environmental determinism that can be used to reduce the responsibility of governments. However, to deny any ecological or climatic element to this conflict is to veer to the other extreme. Environmental stresses, especially droughts, volcanic eruptions and tidal waves, have contributed to the demise of many civilisations. ${ }^{1}$ Unless we change course, there is a high probability that the current trajectory of climate change, resource depletion and ecological loss will undermine our own civilisation. This should motivate intense preventive activity.

Climate change will also contribute to our grossly unequal global food production and distribution. ${ }^{56-61}$ The most authoritative prediction of sea level rise by 2100 is now at least $1 \mathrm{~m}$, far 
more than estimated by the Intergovernmental Panel on Climate Change (IPCC) reports. ${ }^{62} 63 \mathrm{New}$ satellite data have in 2009 revealed an accelerating loss of ice not only from Greenland, ${ }^{64}$ but from West and (for the first time) from East Antarctica. ${ }^{65} \mathrm{~A}$ sea level rise of even a metre by 2100 may thus be conservative; yet even that would displace millions of people from low lying areas. Although some delta cities may find protection through building seawalls, this will be both very expensive and will run the risk of catastrophic failure, as when Hurricane Katrina flooded New Orleans.

\section{THE MEDICAL RESPONSE}

The health professions cannot ignore these gathering population health challenges. Yet, while forecasts of physical disruption from climate change grow more ominous each year, ${ }^{66}$ assessment of the likely social response to these changes remains curiously muted. Insufficient comprehension of these risks is also evident in the health chapter of the 2007 IPCC report, although there is acknowledgement there that the health impacts on economic dislocation and population displacement will be 'substantial'. 67

Straddling both physical and social science, the medical and health professions are in a position to show leadership informed by their understanding of the risk to society posed by these rapidly developing climatic and ecological phenomena. We have proposed a new field of medical practice to help address this challenge. After recognising these risks, ecomedicine can contribute to preventive efforts, on a global scale, aiming especially to minimise or avert the tertiary health consequences of climate and ecological change. We hope that the evidence presented here persuades even the sceptical reader of the growing importance of this field.

Nascent elements of the responses that are needed are growing. These include growing awareness of the scale of the problems by medical colleges in several nations, ${ }^{68}$ by the World Medical Association, ${ }^{69}$ and by many groups of medical activists, including the International Society of Doctors for the Environment. ${ }^{70}$ Some medical schools, especially in Canada, are already teaching elements of ecomedicine. The medical profession cannot respond to these problems on its own. Many other

\section{Key learning points}

- Global health currently faces great challenges due to climatic and other ecological changes. Changes in the Earth's physical system will trigger many health consequences, classified here as primary, secondary and tertiary.

- Examples of primary effects: acute and chronic stress of heatwaves, trauma from increased bushfires and flooding.

- Examples of secondary effects: changes to infectious diseases and atopy and asthma.

- Examples of tertiary effects: large scale migration, famine and conflict.

- Tertiary effects, if they occur, are the most severe, but can still be prevented.

- The medical profession has a long history of involvement in protection of public health and other forms of public goods. We call for the establishment of the new discipline of 'ecomedicine' to study these issues, and to train doctors to contribute to the solution.

\section{Current research questions}

- How can the health effects of the global climatic and ecological change be measured?

- How can future health effects of these changes be measured?

- How can policymakers be persuaded of the potential severity and cost of the tertiary effects of the global climatic-ecological crisis?

- How can medical curriculi be amended to incorporate elements of ecomedicine?

groups are active, and many will be delighted to cooperate with doctors. Yet, even broader and more imaginative alliances are required, perhaps including efforts to persuade military forces to act to prevent-rather than simply respond to-the emerging security threats of climate change and massive migration. ${ }^{71}$

\section{CONCLUSION}

The global climate is changing at a rapid pace, especially at high latitude. Global ecosystems are also faltering and the challenge of Health for All is as elusive as ever. ${ }^{72}$ These problems are 'wicked" because solutions remain so intractable. Analogies exist with the 'wicked' problem of smoking, a common behaviour in which many people in most high income nations, including doctors, engaged during the 1950s and 1960s. Though we have witnessed a lamentable process of denial, subterfuge and protest by the smoking lobby, ${ }^{74}$ the grasp of the tobacco industry upon high income populations has been curtailed. Doctors and medical researchers have made crucial contributions to this advance. As representatives of a socially engaged profession, doctors are positioned to lead as role models in reducing their own carbon footprint. The medical profession has a long history of advocating policies for social change and has an obligation to do so in relation to ecomedicine and global climate.

Many buffers disguise and distance most doctors from the harms that unchecked adverse environmental change will bring. Human behaviours including nihilism, apocalyptic alarmism and use of false science risk disengagement, including by doctors, with these issues. Doctors must be educated about ecomedicine, and learn to recognise its fundamental importance for individual and population health. The health consequences of climatic and ecological change can be lessened or prevented, but the time in which to achieve this is increasingly short.

\section{Actions for doctors and the health system}

Become educated about current and future health consequences of the climatic-ecological change.

- Become a role model. Just as most doctors have ceased smoking, the medical profession should reduce their own ecological footprint, in the clinic and hospital, in their home and by their use of transport.

- Promote active transport and other activities with 'co-benefits' for health and environment.

- Join medical and other groups that act to promote the political, technological and social changes required for the 'sustainability transition'.

- Think and act in ways that reduce global inequalities. 


\section{Timelines}

1940s: formation of United Nations, global consciousness emerges.

1960s: space race, global food crisis, global consciousness develops.

- 1980-2000: period of triumphalism and complacency; fear of global famine recedes. Unfounded faith in technological capacity.

- 2000s: global financial crisis shakes faith in 'expert' capacity. Global climatic-ecological crisis worsens.

- By 2015: Ecomedicine concept embraced widely in medical schools.

- By 2020: Coalitions involving medicine and public health succeed in capping global carbon emissions, and fostering education for all girls, which accelerates global demographic transition.

- By 2025: new technologies spread rapidly, vastly reducing dependency on oil and coal. New forms of agriculture avert food crisis.

- By 2050: Practitioners of ecomedicine continue to act to ensure that tertiary impacts of the still unfolding climatic-ecological crisis are minimised.

\section{Key references}

Allison I, Bindoff NL, Bindschadler RA, et al. The Copenhagen Diagnosis, 2009: updating the world on the latest climate science, The University of New South Wales Climate Change Research Centre (CCRC), Sydney, Australia, 60pp.

Butler CD. Food Security in the Asia-Pacific: climate change, phosphorus, ozone and other environmental challenges Asia Pac $J$ Clin Nutr 2009;18:590-7.

- Harley D, McMichael AJ. Global climate change and infectious diseases: Paradigms, impacts, and future challenges. Infection and Chemotherapy 2008;40:S136-43.

- Lenton TM, Held H, Kriegler E, et al. Tipping elements in the Earth's climate system. Proc Natl Acad Sci U S A 2008;105:1783-5.

- Steffen W, Crutzen PJ, McNeill JR. The Anthropocene: are humans now overwhelming the great forces of nature? Ambio 2007;38:614-21.

\section{MULTIPLE CHOICE QUESTIONS (TRUE (T)/FALSE (F); SEE PAGE 234 FOR ANSWERS)}

1. There is a substantial literature on ecological tipping points and on social tipping points, but surprising little writing that links the two ideas

2. The causal contribution of climate change to the existing burden of disease of malaria is widely accepted

3. The 'Anthropocene' refers to the time since humans developed agriculture

4. Ecomedicine is an attempt to link social science, planetary ecology and global health

5. Unless the climatic- ecological crisis is rapidly addressed, the largest burden of disease is likely to arise from its tertiary health effects
Acknowledgements The authors thank Professor AC Sleigh for his helpful comments on the manuscript

Competing interests Both authors are members of Doctors for the Environment Australia.

Provenance and peer review Commissioned; externally peer reviewed.

\section{REFERENCES}

1. Diamond J. Collapse: how societies choose to fail or succeed. London: Allen Lane, 2005.

2. Lovelock J. The revenge of Gaia. London, UK: Penguin, 2006

3. Rees M. Our final century. London: William Heinemann, 2003.

4. Steffen W, Crutzen PJ, McNeill JR. The Anthropocene: are humans now overwhelming the great forces of nature? Ambio 2007:38:614-21.

5. Eckersley R. What's wrong with the official future? In: Hassan G, ed. After Blair: politics after the New Labour decade. London: Wishart, 2006:172-84.

6. Anon. Health in the greenhouse [editorial]. Lancet 1989;i:819-20.

7. McMichael AJ, Neira M, Heymann DL. World health assembly 2008: climate change and health. Lancet 2008;371:1895-6.

8. Eisenberg L. Rudolf Ludwig Karl Virchow, where are you now that we need you? Am J Med 1984;77:524-32.

9. Kandela P. Medical journals and human rights. Lancet 1998:352:7-12.

10. Anon. Reed elsevier and the arms trade. Lancet 2005;366:868.

11. Ward B, Dubos R. Only one earth: the care and maintenance of a small planet. Harmondsworth: Penguin, 1973.

12. Lovelock J. Gaia: the practical science of planetary medicine. Sydney: Allen and Unwin, 1991.

13. Wilcox BA, Daszak P. Launching the international ecohealth association. Ecohealth 2006:3:125-6.

14. Davey-Smith G. Behind the broad street pump: aetiology, epidemiology and prevention of cholera in mid-19th century Britain. Int J Epidemiol 2002;31:920-32

15. Van Epps HL. René Dubos: unearthing antibiotics. J Exp Med 2006;203:259.

16. Okie S. Global health-the gates-Buffett effect. N Engl J Med 2006;355:1084-8

17. Jha P, Lavery JV. Evidence for global health. Can Med Assoc J 2004;170:1687-8.

18. Smith BJ, Tang KC, Nutbeam D. WHO health promotion glossary: new terms. Health Promot Int 2006:21:340-5.

19. Vernadsky V. The Biosphere. Complete annotated edition. New York: Copernicus, 1998(first published 1926).

20. Crutzen PJ. Geology of mankind: the anthropocene. Nature 2002;415:23

21. Last JM. Public health and human ecology. Stamford, Connecticut: Appleton and Lange, 1998.

22. Rockström J, Steffen W, Noone K, et al. A safe operating space for humanity. Naure 2009;461:472-5

23. Blais JM, Schindler DW, Muir DCG, et al. Accumulation of persistent organochlorine compounds in mountains of western Canada. Nature 1998;395:585-8.

24. Grandjean P, Bellinger D, Bergman $\AA$, et al. The Faroes statement: human health effects of developmental exposure to chemicals in our environment. Basic Clin Pharmacol Toxicol 2007;102:73-5.

25. Binswanger HC, Smith KR. Paracelsus and Goethe: founding fathers of environmental health. Bull World Health Organ 2000;78:1162-5.

26. Weart SR. The discovery of global warming. Cambridge, MA: Harvard University Press, 2003.

27. Leaf A. Potential health effects of global climatic and environmental changes. New Engl J Med 1989;321:1577-83

28. Butler CD, Corvalán CF, Koren HS. Human health, well-being and global ecological scenarios. Ecosystems 2005;8:153-62.

29. Kovats RS, Hajat S. Heat stress and public health: a critical review. Annu Rev Public Health 2008;29:41-55.

30. Hashizume $\mathbf{M}$, Wagatsuma $Y$, Hayashi $T$, et al. The effect of temperature on mortality in rural Bangladesh - a population based time-series study. Int J Epidemiol 2009:38:1689-97.

31. Dear K. Commentary: on Hashizume et al.'s 'The effect of temperature on mortality in rural Bangladesh'. Int J Epidemiol 2009:38:1697-9.

32. Nicholls N. Estimating changes in mortality due to climate change. Clim Change 2009;97:313-20.

33. Huntingford C, Gash J. Climate equity for all. Science 2005;309:1789

34. Travis J. Scientists' fears come true as hurricane floods New Orleans. Science 309:1656-9

35. Beggs $\mathbf{P}$, Bambrick $H$. Is the global rise of asthma an early impact of anthropogenic climate change?. Environ Health Perspect 2005;113:915-19.

36. Ziska LH, Epstein PR, Schlesinger WH. Rising CO2, climate change, and public health: exploring the links to plant biology. Environ Health Perspect 2009;117:155-8.

37. Dear K, Ranmuthugala G, Kjellström T, et al. Effects of temperature and ozone on daily mortality during the August 2003 heat wave in France. Arch Environ Occup Health 2005;60:205-12.

38. Kinney PL. Climate change, air quality, and human health. Am J Prev Med 2008:355:459-67.

39. Dobson A. Climate variability, global change, immunity, and the dynamics of infectious diseases. Ecology 2009;90:920-7.

40. Lafferty KD. The ecology of climate change and infectious diseases. Ecology 2009;90:888-900. 
41. Pascual M, Bouma MJ. Do rising temperatures matter? Ecology 2009;90: 906-12.

42. Ostfeld RS. Climate change and the distribution and intensity of infectious diseases. Ecology 2009;90:903-5.

43. Randolph SE. Perspectives on climate change impacts on infectious diseases. Ecology 2009;90:927-31.

44. Reiter P, Thomas CJ, Atkinson PM, et al. Global warming and malaria: a call for accuracy. Lancet Infect Dis 2004;4:323-4.

45. Harley D, Sleigh A, Ritchie S. Ross River virus transmission, infection, and disease: a cross-disciplinary review. Clin Microbiol Rev 2001;14:909-32.

46. McMichael AJ, Woodruff RE. Climate change and infectious diseases. In: Mayer $\mathrm{KH}$, Pizer HF, eds. The social ecology of infectious diseases. Amsterdam: Elsevier, 2008:378-407.

47. Zhou X-N, Yang G-J, Yang K, et al. Potential impact of climate change on schistosomiasis transmission in China. Am J Trop Med Hyg 2008;78:188-94.

48. Pettersson L, Boman J, Juto P, et al. Outbreak of Puumala virus infection, Sweden. Emerg Infect Dis 2008;14:808-10.

49. Harley D, McMichael AJ. Global climate change and infectious diseases: Paradigms, impacts, and future challenges. J Infect Chemother 2008;40:S136-43.

50. Tanser FC, Sharp B, le Sueur D. Potential effect of climate change on malaria transmission in Africa. Lancet 2003;362:1792-8.

51. Hales S, de Wet N, Maindonald J, et al. Potential effect of population and climate changes on global distribution of dengue fever: an empirical model. Lancet 2002;360:830-4.

52. Halstead S. Dengue virus-mosquito interactions. Annu Rev Entomol 2008;53:273-91.

53. Lenton TM, Held $\mathrm{H}$, Kriegler $\mathrm{E}$, et al. Tipping elements in the Earth's climate system. Proc Natl Acad Sci U S A 2008;105:1783-5

54. Sachs J. Poverty and environmental stress fuel Darfur crisis. Nature 2007:449:14-15.

55. United Nations Environment Programme. Sudan: post-conflict environmental assessment. 2007. http://www.unep.org/sudan/ (accessed Nov 2009).

56. Battisti DS, Naylor RL. Historical warnings of future food insecurity with unprecedented seasonal heat. Science 2009;323:240-4.

57. Easterling WE. Climate change and the adequacy of food and timber in the $21^{\text {st }}$ century. Proc Natl Acad Sci U S A 2007;104:19679.

58. Lobell DB, Burke MB, Tebaldi C, et al. Prioritizing climate change adaptation needs for food security in 2030. Science 2008;319:607-10.

59. Long SP, Ainsworth EA, Leakey ADB, et al. Food for thought:lower-than-expected crop yield stimulation with rising CO2 concentrations. Science 2006;312:1918-21.

60. Schmidhuber J, Tubiello FN. Global food security under climate change. Proc Natl Acad Sci U S A 2007;104:19703-8.
61. Butler CD. Food Security in the Asia-Pacific: climate change, phosphorus, ozone and other environmental challenges. Asia Pac J Clin Nutr 2009;18:590-7.

62. Rahmstorf S, Cazenave A, Church JA, et al. Recent climate observations compared to projections. Science 2007;316:709.

63. Allison I, Bindoff NL, Bindschadler RA, et al. The Copenhagen Diagnosis, 2009. updating the world on the latest climate science. Sydney, Australia: The University of New South Wales Climate Change Research Centre (CCRC), 2009: 60.

64. van der Broeke M, Bamber J, Ettema J, et al. Partitioning recent Greenland mass loss. Science 2009:326:984-6.

65. Chen JL, Wilson CR, Blankenship D, et al. Accelerated Antarctic ice loss from satellite gravity measurements. Nat Geosci 2009. Published Online First: 22 Nov 2009, doi:10.1093.ije/dyp271.

66. Smith JB, Schneider SH, Oppenheimer M, et al. Assessing dangerous climate change through an update of the intergovernmental panel on climate change (IPCC) "reasons for concern". Proc Natl Acad Sci U S A 2009:106:4133-7.

67. Confalonieri U, Menne B, Akhtar R, et al. Human health. Climate change 2007 impacts, adaptation and vulnerability. Contribution of working group II to the fourth assessment report of the intergovernmental panel on climate change. In: Parry ML, Canziani OF, Palutikof JP, et al. eds. Cambridge, UK: Cambridge University Press, 2007:391-431

68. Lim V, Stubbs JW, Nahar N, et al. Politicians must heed health effects of climate change. Lancet 2009;374:973.

69. World Medical Association. Declaration of Delhi on health and climate change 2009 http://www.wma.net/en/30publications/10policies/c5/index.html (accessed Nov 2009).

70. International Society of Doctors for Environment (ISDE). http://www.isde.org/ (accessed Nov 2009)

71. Wright S. Emerging military responses to climate change - the new technopolitic of exclusion. IOP Conf Ser: Earth and Environ Sci 2009:6:562003.

72. Butler CD. Sustainable health for all by the year 2100? Int J Public Health 2008:53:223-4.

73. Rittel H, Webber M. Dilemmas in a general theory of planning. Policy Sci 1973:4:155-69.

74. Garne D, Watson M, Chapman S, et al. Environmental tobacco smoke research published in the journal indoor and built environment and associations with the tobacco industry. Lancet 2005:365:804-9.

\section{ANSWERS}

1. 1 (T); 2 (F); 3 (F); 4 (T); 5 (T) 